\title{
Single colony genetic analysis of epilithic stream algae of the genus Chamaesiphon spp.
}

\author{
Rainer Kurmayer $\mathbb{D}$ - Guntram Christiansen • Andreas Holzinger • \\ Eugen Rott
}

Received: 8 April 2017/Revised: 21 June 2017/Accepted: 30 June 2017/Published online: 21 August 2017

(C) The Author(s) 2017. This article is an open access publication

\begin{abstract}
In order to understand Chamaesiphon spp. evolution and ecological diversification, we investigated the phylogenetic differentiation of three morphospecies from field samples by means of single colony genetics. Individual colonies of three different morphospecies (C. starmachii, C. polonicus, C. geitleri,) were isolated from lotic gravel streams and their $16 \mathrm{~S}$ rDNA nucleotide variability was analyzed. For a number of individual colonies, microscopical and ultrastructural analysis was also performed. A phylogenetic tree of all major lineages of the phylum of Cyanobacteria assigned all Chamaesiphon genotypes (1149-1176 bp) most closely with the family of Gomontiellaceae of the order Oscillatoriales. The sequences obtained from colonies assigned to $C$. starmachii $(n=21), C$. polonicus $(n=9)$, and $C$.
\end{abstract}

Electronic supplementary material The online version of this article (doi:10.1007/s10750-017-3295-z) contains supplementary material, which is available to authorized users.

Guest editors: Eugen Rott, Allan Pentecost \& Jan Mares / Aspects of cyanobacterial biogeography, molecular ecology, functional ecology and systematics

R. Kurmayer $(\bowtie) \cdot$ G. Christiansen

Research Institute for Limnology, University of Innsbruck, Mondseestraße 9, 5310 Mondsee, Austria

e-mail: rainer.kurmayer@uibk.ac.at

A. Holzinger - E. Rott

Institute of Botany, University of Innsbruck,

Sternwartestraße 15, 6020 Innsbruck, Austria geitleri $(n=17)$ were found to reveal high average $(3.5 \%)$ nucleotide diversity. No phylogenetic subbranching in correspondence with morphology was observed suggesting that the three Chamaesiphon morphospecies did not represent monophyletic taxa. We could not attribute specific thylakoid ultrastructure to phylogenetic sub-branches; however, the observed parietally and loosely arranged thylakoids indicate that for the genus Chamaesiphon, the variability in thylakoid ultrastructure might have been underestimated. In summary, the high nucleotide diversity of the 16S rDNA gene implies phylogenetic diversity that corresponds little to morphological classification.

Keywords Gravel streams - Heteropolar cyanobacteria - Bioindication - Single colony PCR . 16S rDNA gene sequencing

\section{Introduction}

The cyanobacterial morphogenus Chamaesiphon represents one of the most widespread taxa forming thin biofilms in mountain rivers worldwide (e.g., Bürgi et al., 2003; Rott et al., 2006; Rott, 2008; Sant'Anna et al., 2011; Scott \& Marcarelli, 2012; Gutowski et al., 2015). Several Chamaesiphon species can cover up to $>70 \%$ of the wetted perimeter in clear mountain streams (Rott \& Wehr, 2016). The genus Chamaesiphon was recorded over a broad range of 
environmental situations in respect to (i) light (i.e., from shaded to highly light (UV) exposed sites), (ii) pH (i.e., from acid to alkaline, Cantonati et al., 2007) and (iii) nutrients (i.e., from ultra-oligotrophic to eutrophic conditions, Rott et al., 1999; Rott \& Schneider, 2014). Up to date, 33 species of the morphogenus Chamaesiphon have been validly described under the rules of the Botanical Nomenclatoric Code (ICBN, Komárek \& Anagnostidis, 1999, and Cyano Database: http://www.cyanodb.cz, February, 2017). These cyanobacterial species are distinguished based on morphological characters, and although some morphological characters are less stable than others, several of the morphospecies of the genus Chamaesiphon have been recorded repeatedly from different regions in the world (e.g., Komárek \& Anagnostidis, 1999; Rott \& Wehr, 2016). Microbiological typification defines the morphogenus Chamaesiphon as a simple unicellular cyanobacterium with typical asymmetrical binary fission (called budding or exocyte or exospore formation) produced at one pole of the mother cell, where typically one single or a consecutive large series of small exospores (or small buds) is formed (Herdman et al., 2001).

Colony forming cyanobacteria can reach a macroscopically visible size from clonal cellular growth. This facilitates the isolation of single individuals directly from field samples for analyses of their genetics, cyanotoxins or other bioactive secondary metabolites (e.g., Kurmayer et al., 2002). Advanced molecular techniques have increased the sensitivity of PCR, resulting in the possibility to amplify DNA fragments from just picograms of template DNA, such as from single colonies of cyanobacteria. This makes it possible to perform dozens of PCR experiments amplifying large DNA fragments ( $>1000 \mathrm{bp})$ from a single specimen (e.g. Chen et al., 2016). Combining the field-based techniques with advanced molecular biological methods holds great potential to analyze the ecological, as well as phylogenetic, diversification of cyanobacteria, particularly if they are difficult to cultivate (e.g., Mareš \& Cantonati, 2016). In general, a detailed molecular resolution of Chamaesiphon morphospecies might allow a better characterization of running water habitats that are under environmental stress induced by regional climate change or by anthropogenic influence (e.g., Loza et al., 2013).

The aim of this study was to characterize Chamaesiphon morphospecies using molecular biological techniques on the individual (single colony) scale, which would allow to relate morphological descriptors to genotype variability. We speculated that morphological differentiation might correlate with phylogeny, even between morphospecies, because of selective environmental pressure resulting in phylogenetically distinct ecotypes. For example, high mechanical pressure in lotic ecosystems may lead to morphospecies forming a multilayered cell wall and growing in colonies (assigned to Chamaesiphon subgenus Godlewskia, Komárek \& Kaštovský, 2003; Hoffmann et al., 2005) specialized to grow in the viscous sublayer on solid substrates. Thus, the question arises whether it is possible to characterize individual Chamaesiphon morphospecies by molecular taxonomic markers such as $16 \mathrm{~S}$ rDNA genes and/or the more variable internal transcribed spacer regions.

\section{Materials and methods}

Study organisms and sampling area

In alpine gravel streams, epilithic Chamaesiphon species were recognized forming small patches $(C$. starmachii Kann 1972, C. geitleri Luther 1954) or thin and sometimes extended covers (C. polonicus (Rostafinski) Hansgirg 1892), see Fig. 1. The two sampling sites included crystalline geology (Nederbach, Ochsengarten, near Kühtai, Tyrol, Austria) and carbonaceous basement (Isar River, Scharnitz, near Seefeld, Tyrol and Karwendelbach, a tributary of Isar River, see Table 1).

In addition, the following Chamaesiphon strains available from culture collections were used (Table 2): C. minutus (PCC 6605), C. subglobosus (PCC 7430) (Rippka et al., 1979), C. polonicus (SAG 32.87), C. polymorphus Geitler 1925 (CCALA Hindák 1984/5). Two Chamaesiphon morphospecies were isolated following established protocols (Chu, 1942): epilithic growing $C$. geitleri from Gschnitzbach (Trins, Tyrol, $47^{\circ} 04^{\prime} 38.73^{\prime \prime} \mathrm{N}, \quad 11^{\circ} 24^{\prime} 46.46^{\prime \prime} \mathrm{O}$, $1191 \mathrm{~m}$ ), and the epiphytic morphospecies $C$. cf. incrustans from a small spring (Nature Reserve Fontanili di Corte Val Rei, near Reggio Emilia, Italy $44^{\circ} 46^{\prime} 2^{\prime \prime} \mathrm{N}, 10^{\circ} 31^{\prime} 58^{\prime \prime} \mathrm{E}, 30 \mathrm{~m}$ a.s.1.). In order to obtain purified clonal cultures the strains were streaked on agar repeatedly. 

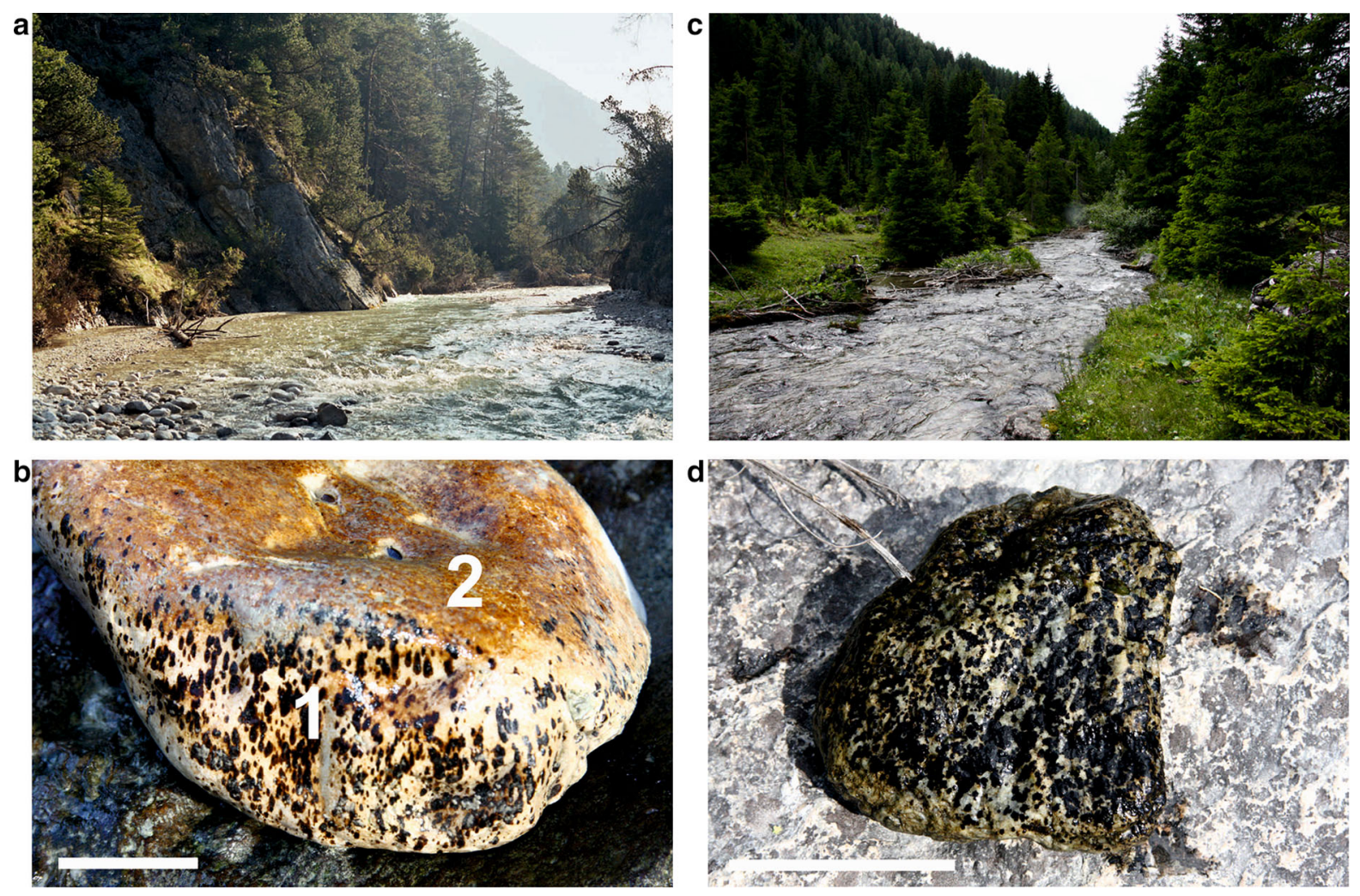

Fig. 1 a Calcareous river Isar (Tyrol) and b pebble from Isar with (1) dark brown spots formed by $C$. geitleri on the lateral river Nederbach and $\mathbf{d}$ pebble from Nederbach with black spots formed by $C$. starmachii. Scale bars $5 \mathrm{~cm}$ side and (2) red crust formed by $C$. polonicus, c central alpine

Table 1 Sampling sites and observed Chamaesiphon spp. morphospecies

\begin{tabular}{|c|c|c|c|c|c|}
\hline Site & Coordinates & $\begin{array}{l}\text { Altitude } \\
\text { (m. a. SL.) }\end{array}$ & $\begin{array}{l}\text { Parameters } \\
\text { (Cond. }{ }^{\mathrm{a}}, \text { Temp, pH) }\end{array}$ & $\begin{array}{l}\text { Chamaesiphon } \\
\text { morphospecies }\end{array}$ & Sampling Date \\
\hline $\begin{array}{l}\text { Nederbach (Ochsengarten or } \\
\text { Zirmbach) }\end{array}$ & $\begin{array}{l}47^{\circ} 13^{\prime} 45.16^{\prime \prime} \mathrm{N} \\
10^{\circ} 57^{\prime} 28.98^{\prime \prime} \mathrm{O}\end{array}$ & 1593 & $46 \mu \mathrm{S}, 10^{\circ} \mathrm{C}, \mathrm{pH} 7.3$ & C. starmachii & $\begin{array}{l}\text { Nov'09, Apr'10, } \\
\text { Apr'11 }\end{array}$ \\
\hline Isar (Scharnitz, Isarursprung) & $\begin{array}{l}47^{\circ} 23^{\prime} 01.86^{\prime \prime} \mathrm{N} \\
11^{\circ} 16^{\prime} 20.49^{\prime \prime} \mathrm{O}\end{array}$ & 980 & $200 \mu \mathrm{S}, 5^{\circ} \mathrm{C}, \mathrm{pH} 8$ & $\begin{array}{l}\text { C. polonicus, } \\
\text { C. geitleri, }\end{array}$ & $\begin{array}{l}\text { Apr'10, Apr'11, } \\
\text { Oct'15 }\end{array}$ \\
\hline $\begin{array}{l}\text { Karwendelbach (Scharnitz, } \\
\text { Isarursprung) }\end{array}$ & $\begin{array}{l}47^{\circ} 22^{\prime} 49.53^{\prime \prime} \mathrm{N} \\
11^{\circ} 17^{\prime} 05.41^{\prime \prime} \mathrm{O}\end{array}$ & 984 & $800 \mu \mathrm{S}, 9^{\circ} \mathrm{C}, \mathrm{pH} 8$ & C. polonicus & Apr'10 \\
\hline
\end{tabular}

a Conductivity $\left(\mu \mathrm{S} \mathrm{cm}^{-1}\right)$

Single Chamaesiphon colony isolation

From the sampling sites, individual pebbles overgrown with Chamaesiphon were sampled and transported into the laboratory under cold and dark conditions. Individual Chamaesiphon colonies $(C$. starmachii, C. polonicus, C. geitleri) were directly selected and isolated from the substratum under the dissecting microscope using a sterile razor blade and a needle. The individual colonies were transferred to an agar plate (2\% agarose, Chu, 1942) and purified by moving the colony gently on agar using a fine sterile wire loop and a sterile fine needle. Aliquots of individual colonies were stored in $10 \mu$ Millipore 
Table 2 Clonal cultures of Chamaesiphon spp.

\begin{tabular}{llll}
\hline Strain name & $\begin{array}{l}\text { Date } \\
\text { isolated }\end{array}$ & Origin & Morphospecies \\
\hline $\begin{array}{l}\text { CCALA HINDAK } \\
\text { 1984/5 }\end{array}$ & 1984 & Lake Millstätter See (AT) & C. polymorphus \\
PCC 6605 & 1966 & Stream, Berkeley, California (USA) & C. minutus \\
PCC 7430 & 1963 & Stream, Sarka Valley near Prague (CR) & C. subglobosus \\
PCC 8308 & 1983 & Epiphyte on Cladophora sp., from Lake Vierwaldstättersee, & Chamaesiphon \\
SAG 32.87 & 1965 & Kastanienbaum (CH) & Stansstad, moist rocks (CH) \\
No. 1036 & 2012 & Epolonicus \\
No. 1022, 1023, 1024 & 2014 & Gschnitzbach, near Trins, Tirol (AT) & C. cf. incrustans \\
\hline
\end{tabular}

CCALA Culture collection of autotrophic organisms Institute of Botany CAS, Trebon, PCC Pasteur culture collection, SAG Sammlung Algenkulturen Göttingen

water. One aliquot was used as PCR template and stored frozen $\left(-20^{\circ} \mathrm{C}\right)$. Another aliquot of the colony was assigned to morphospecies identification according to Komárek \& Anagnostidis (1999). A third aliquot was used for TEM analysis.

Light- and transmission electron microscopy

Light microscopy was performed using a Zeiss Axiovert $200 \mathrm{M}$ microscope and images were captured with a Zeiss Axiocam Mrc 5 and an Olympus BMX50 microscope with a ProGresCT3 camera, respectively. Transmission electron microscopy was performed as described (Holzinger et al., 2009). Briefly, cells were fixed with $2.5 \%$ glutaraldehyde for $1.5 \mathrm{~h}$ at room temperature, followed by a fixation in $1 \% \mathrm{OsO}_{4}$ at $4{ }^{\circ} \mathrm{C}$ overnight (18 h), both in $50 \mathrm{mM}$ caccodylate buffer $(\mathrm{pH}$ 6.8). Samples were dehydrated in increasing ethanol concentrations, embedded in modified Spurr's resin and heat polymerized at $80^{\circ} \mathrm{C}$. Ultrathin sections were prepared and viewed at a Zeiss Libra 120 transmission electron microscope $(80 \mathrm{kV})$ connected to a ProScan $2 \mathrm{k}$ SSCCD camera, operated by OSIS iTEM software. Images were processed with Adobe Photoshop elements 11. Cyanobacterial inclusions were assigned according to the recent catalog of cyanobacterial ultrastructure, i.e., the carboxysomes were recognized as electron dense bodies (Gonzalez-Esquer et al., 2016).

\section{Single Chamaesiphon colony PCR}

Single colonies were dispersed using ultrasonication and suspended in PCR sample dilution buffer resulting in $50 \mu \mathrm{l}$ total colony sample volume as described (Chen et al., 2016). The extracted DNA was used directly as a template for PCR amplification of the 16S rDNA and internal transcribed spacer (ITS) region (359F, 23S30R, ca. $1.6 \mathrm{kbp}$, Taton et al., 2003). In a pilot experiment, a number of colonies were tested for successful PCR amplification using two different PCR DNA-polymerases (i) a classical Taq polymerase (DreamTaq DNA Polymerase, Thermo Fisher Scientific, Darmstadt, Germany) and (ii) the engineered high speed, proof-reading polymerase (Phusion, Thermo Fisher Scientific). The PCR amplifications were performed in a total volume of $25 \mu \mathrm{l}$. For the DreamTaq PCR, the reaction mixture included $2.5 \mu$ l DreamTaq PCR Buffer $\left(10 \times\right.$, including $\left.20 \mathrm{mM} \mathrm{MgCl}_{2}\right), 1.0 \mu \mathrm{l} \mathrm{MgCl}_{2}$ (25 mM), $0.75 \mu \mathrm{dNTPs}(10 \mathrm{mM}$ each), $0.75 \mu \mathrm{l}$ of each primer $(10 \mu \mathrm{M}$ each), $0.15 \mu \mathrm{l}$ of DreamTaq polymerase, $16.6 \mu \mathrm{l}$ sterile Millipore water, and $2.5 \mu \mathrm{l}$ of template. For the Phusion PCR the reaction mixture included $5 \mu \mathrm{l}$ of $(5 \times)$ Phusion GC reaction buffer, $0.5 \mu \mathrm{l}$ of dNTPs, $1.25 \mu \mathrm{l}$ of each primer $(10 \mu \mathrm{M}), 0.25 \mu \mathrm{l}$ of Phusion DNA polymerase, $14.25 \mu \mathrm{l}$ sterile Millipore water and $2.5 \mu \mathrm{l}$ DNA template. For the DreamTaq/Phusion PCR, the thermal cycling protocol included an initial denaturation step at $94^{\circ} \mathrm{C}(3 \mathrm{~min}) / 98^{\circ} \mathrm{C}(30 \mathrm{~s})$, followed by 35 cycles including denaturation at $94^{\circ} \mathrm{C}(30 \mathrm{~s}) / 98^{\circ} \mathrm{C}$ $(10 \mathrm{~s})$, annealing at $60^{\circ} \mathrm{C}(30 \mathrm{~s}) / 60^{\circ} \mathrm{C}(15 \mathrm{~s})$, and elongation $72^{\circ} \mathrm{C}(1.5 \mathrm{~min}) / 72^{\circ} \mathrm{C}(30 \mathrm{~s})$. During a pilot experiment, the Dream Taq Polymerase had little PCR success and was not used further. Using the Phusion polymerase, we were able to amplify the 
16S rDNA from the majority of the isolated colonies from three different morphospecies (Table S1).

Clone library, RFLP-typing and sequencing

To identify rDNA genotypes of individual Chamaesiphon colonies, for each morphospecies the obtained 16S rDNA-ITS PCR products (1.6 kbp) were purified and ligated into the pJet-Cloning Vector system (Thermo Fisher Scientific) and cloned through subsequent transformation of Escherichia coli (strain K 12) following manufacturer's instructions. Purified plasmids were sequenced from both directions using pJet-Cloning Vector standard primers and assembled sequences were submitted to DDBJ/EMBL/Genbank under the accession no. KY704109-KY704162 (Table S2).

In a pilot experiment, for two colony samples of the three Chamaesiphon morphospecies (C. starmachii, C. polonicus, $C$. geitleri), 20 colonies were randomly selected and dissolved in $10 \mu \mathrm{l}$ of Millipore water and $1 \mu \mathrm{l}$ was used as template for PCR amplification using the same primers (see above). Subsequent restriction analysis (AluI) revealed the genetic diversity within the individual Chamaesiphon colony samples as well as potentially co-occurring other cyanobacteria. By this method, when comparing the AluI restriction profile between the amplified and sequenced PCR product from strain C. minutus PCC 6605 (1798 bp, access no. KY704112) and the three copies of $16 \mathrm{~S}$ rDNA-ITS-23S rDNA (1798 bp) in the sequenced genome (Shih et al., 2013) identical restriction profiles were obtained (8 substitutions, $99.5 \%$ similarity). When comparing different morphospecies from the individual Chamaesiphon colonies one to three AluI restriction types were observed (Table S1). In only one case a restriction type (1044 bp) with $99 \%$ sequence identity to Microcoleus vaginatus SAG 22.11 (EF654074.1) occurred. Since cyanobacteria other than Chamaesiphon were amplified and sequenced in a single case only, it was concluded that the single colony isolation technique was reproducible for the genus Chamaesiphon, while the influence of other potentially co-occurring cyanobacterial taxa on the PCR results was of minor importance.

Statistical and phylogenetic analysis

Sequences were aligned and conserved motifs were analyzed according to Iteman et al. (2000). While the
16S rDNA comprised 1149-1176 bp until the highly conserved motif D1 (Table 3), the ITS region was located between the highly conserved motif D1 and the less conserved motif D5 resulting in 608-681 bp. The sequence similarity was calculated using the PHYLIP package (version 3.69, Felsenstein, 2004). All obtained 16S rDNA sequences (1149-1176 bp) were included in a phylogenetic tree constructed from previously described cyanobacterial taxa comprising all major lineages of the phylum (Wilmotte \& Herdmann, 2001) as well as clades found related to Chamaesiphon more recently (Bohunická et al., 2015; Mareš \& Cantonati, 2016). In total, 150 non-redundant sequences obtained from strains were downloaded from the Ribosomal Database Project (RDP), Cole et al., 2014 (Table S3). The 16S rDNA phylogenetic tree was constructed by maximum likelihood method using the program RAxML 8.0.26 (Stamatakis, 2014), executing 1000 rapid bootstrap inferences and thereafter a thorough ML search. Likelihood of the final tree was evaluated and optimized using a Gamma substitution matrix (GTR).

\section{Results}

Light microscopical characterization of Chamaesiphon morphospecies

The three morphospecies sampled from the field had macroscopically visible features as follows: $C$. starmachii and $C$. geitleri were forming dark brown to almost black coatings (thickness $0.1-1 \mathrm{~mm}$ ) on stony substrates (a few square millimeters were typical for C. starmachii and C. geitleri in early stages; older colonies of $C$. starmachii also formed extended coatings). In contrast $C$. polonicus colonies did not form thicker delimited patches and were characterized by thin covers or crusts colored orange to dark redbrown (Fig. 1).

The microscopical aspects of young stages of all three morphospecies were first colorless and similar to each other. However, later in growth typical morphological differences of the three taxa became evident, i.e., a gradual coverage by several specifically pigmented layers of exopolymers (pseudovaginae). $C$. starmachii had an inverse egg-shaped to cylindrical form (Fig. 2a), C. polonicus cells were broad spherical sometimes cup-shaped or pear-shaped and formed 
Table 3 Summary of 16S rDNA variability from Chamaesiphon strain cultures and individually isolated Chamaesiphon morphospecies colonies

\begin{tabular}{llclc}
\hline Chamaesiphon species & Length (bp) min-med-max & Max. dissimilarity $(\%)$ & Average similarity $(\%)$ & $N$ \\
\hline C. starmachii & $1158-1168-1176$ & 14.7 & 96.2 & $21(15)$ \\
C. polonicus & $1166-1168-1173$ & 6.3 & 97.5 & $9(5)$ \\
C. geitleri & $1149-1167-1169$ & 6.0 & 98 & $17(6)$ \\
Chamaesiphon spp. (strains) & $1162-1167-1169$ & 9.6 & 95.6 & $7(7)$ \\
Total & $1149-1168-1176$ & 15.0 & 96.5 & 54 \\
\hline
\end{tabular}

$N$ Number of sequences (individual colonies)

ellipsoid persisting stages narrowing at the base (Fig. 2b), and C. geitleri cells were mostly of elongated elliptic shape with a short inverse eggshaped basis (Fig. 2c). Exospores (buds) of all three species were primarily spherical but developed differently between the three species. C. geitleri pseudosporangia developed into elongated cells (five to eight fold longer than wide), C. starmachii pseudosporangia also grew in length (but only three to five fold longer than wide), whereas $C$. polonicus pseudosporangia were only two to three fold longer than wide. Maturing cells of all three morphospecies formed gradually multilayered extracellular sheath coatings (pseudovagina) before the sheath is breaking at the apex thereby releasing the naked exospores. The thickest and most multilayered dark yellow to brown colored pseudovagina was found in $C$. geitleri. The pseudovagina of $C$. polonicus was normally orange to dark red-brown colored. Under desiccated conditions, C. polonicus lost its thick pseudovagina layers and the cell shape became regularly elongated and elliptic with striking red pigmentation. The mature cells differed in size between the three taxa (Table S1). Cultivated strains PCC 6605 (C. minutus), PCC 7430 (C. subglobosus), and strain No.1036 (C. cf. incrustans) typically lost their sheaths, but kept asymmetric cell division (Fig. 2d-f). The strain culture of $C$. cf. incrustans also showed heteropolar cells forming exocytes at one side of the elongated mother cell.

\section{Ultrastructural characterization of Chamaesiphon morphospecies}

The ultrathin cross section of several C. starmachii colonies exhibited variations of cell shapes and sizes arranged in multiple layers with older (darker) cells in the basal part of the colony (showing a thick apically frayed or widely open pseudovagina and a conical cell basis), and younger (smaller) cells in the upper layers respectively (Fig. 3a). Three different stages of unequal binary fission/division with perpendicular cross walls and gradual separation of increasing elliptic naked single exospores were observed (as marked by asterisks). The cellular ultrastructure of a mature pseudosporangium of C. starmachii showed a mostly peripheral arrangement of a number of noncontinuous bundles of thylakoids (4-5-6 irregular broken arrays) (Fig. 3b, c). Within the cytoplasm distinct central areas with medium electron density and no thylakoids were observed (Fig. 3c).

A similar cell architecture was observed for $C$. polonicus (Fig. 3d-f), however, with pores perforating the cell wall enriched in the lower (basal) part of the cell (Fig. 3e, f), which are putatively used for mucilage secretion. Cross sections of $C$. polonicus showed a mature pseudosporangium with a partly frayed thick dark pigmented slime layer in the upper part, before releasing the exospores (Fig. 3d). Double membranes of thylakoids were visible (Fig. 3e). In this case, the irregularly bent thylakoids appeared to cover almost the whole cell cross section.

In $C$. geitleri, there was a distinct arrangement of the thylakoid bundles (mostly 3-4) parallel to the cell wall (Fig. 3g-i). Only few individual thylakoids were also found in the cell center (Fig. 3h). The sheath on the outer side of the cell wall had an irregular appearance (Fig. 3i). In Fig. $3 \mathrm{~g}$ and $\mathrm{h}$ presumably young cells of $C$. geitleri started to grow in length. The lower part of an exosporangium had a thicker but less pigmented mucilage layer as compared with an older cell showing very thick and dark pigmented sheath layers (Fig. 3i). Compared with other morphospecies 

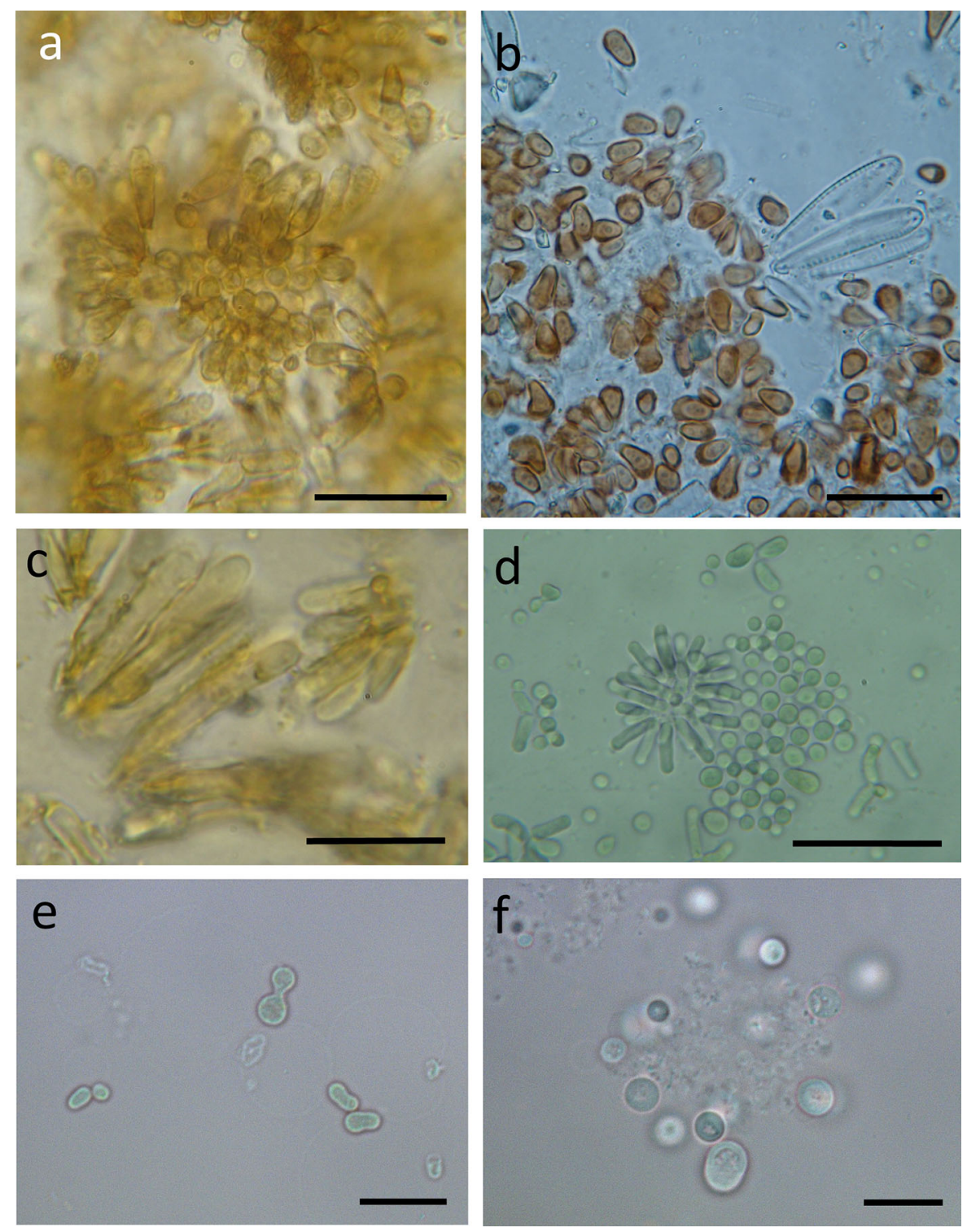

Fig. 2 Light micrographs of Chamaesiphon spp. a-c squash slide samples of field material and $\mathbf{d}-\mathbf{f}$ cultivated strains. a $C$. starmachii from Nederbach, b C. polonicus from River Isar, c $C$.

geitleri from River Isar, d C. cf. incrustans strain No. 1036, e strain PCC 6605 (C. minutus), f strain PCC 7430 (C. subglobosus). Scale bars: a, d $20 \mu \mathrm{m}, \mathbf{b}: 15 \mu \mathrm{m}$, c, e, f: $10 \mu \mathrm{m}$

the number of thylakoids was lower and in some cases additional thylakoids in the cell center were visible (e.g. in Fig. 3h). Further details of the cells constituents included carboxysomes in the cell center, lipid bodies, and glycogen granules (see the abbreviations in Fig. 3).

Cells from Chamaesiphon strain cultures had a distinct ultrastructure, without additional sheath layers covering the cells. In general, the uneven cell division

was maintained under culture conditions (e.g., Figure 4a). In Fig. 4b, the cell constituents were found almost disintegrated. Chamaesiphon cf. incrustans strain No. 1036 was isolated from a rich epiphytic layer of long mature exosporangia assigned to $C$. cf. incrustans with a one-layered transparent pseudovagina. Under culture conditions the cells lost the pseudovagina and showed either thylakoid membranes parallel to the cell wall or a more irregular 

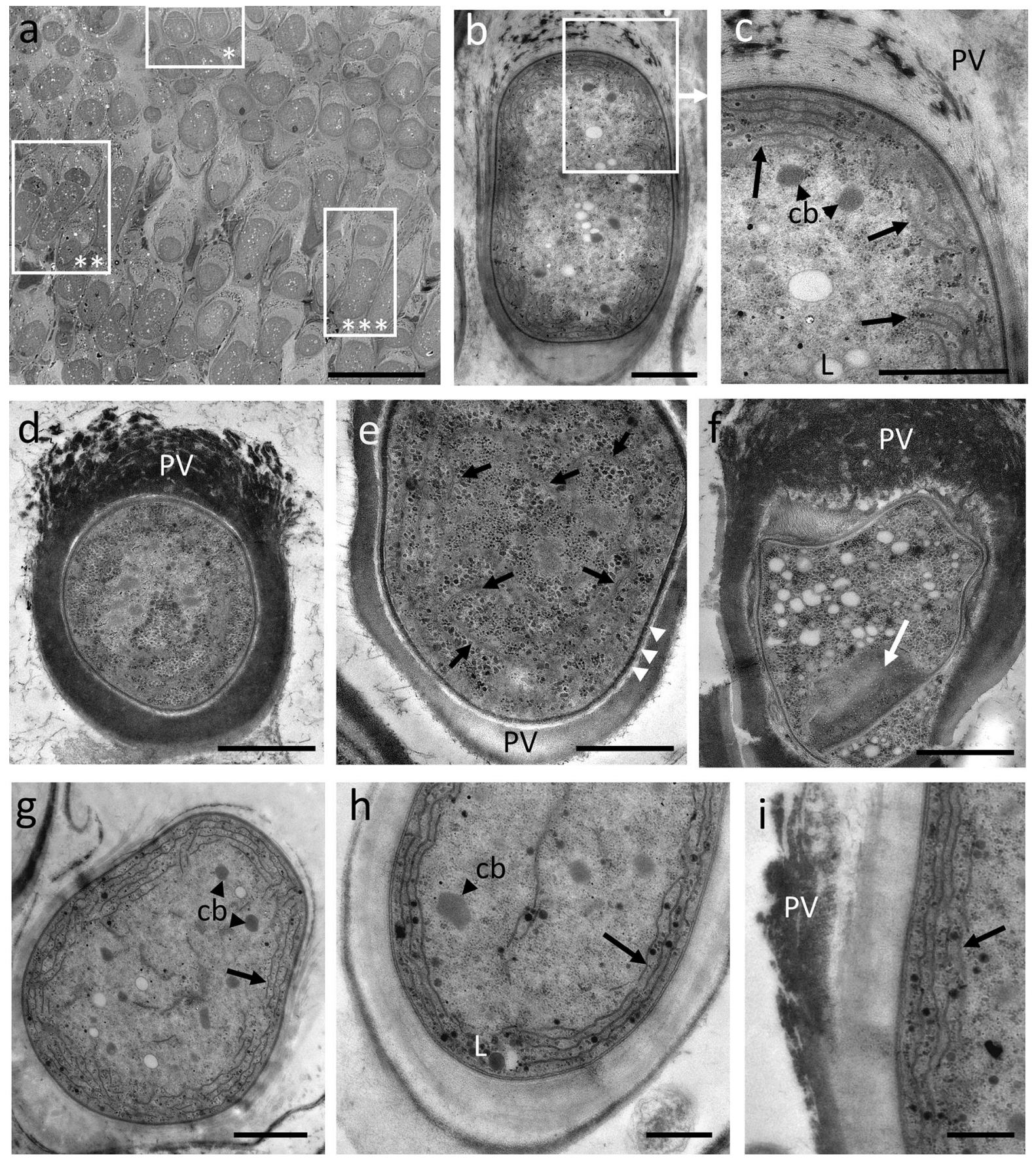

thylakoid distribution (Fig. 4a). Notably, C. minutus (PCC 6605, Fig. 4b, c) and C. subglobosus (PCC 7430, Fig. 4d, e) showed large areas with numerous distinct thylakoid membranes parallel to the cell wall. In tangential sections, the thylakoid membranes were distributed over the whole area (Fig. 4c, e).
Genetic variability within individual Chamaesiphon colonies and between morphospecies

In total fifteen individual colonies of $C$. starmachii (resulting in 21 sequences), five individual colonies of 
4Fig. 3 Transmission electron micrographs of field samples of Chamaesiphon spp. a-c C. starmachii from Nederbach: a cross section of multilayered cell aggregation; asterisks indicate three successive stages of unequal cell budding, b C. starmachii, mature pseudosporangium with upward broken pseudovagina, c detail of b showing several peripheral bundles of thylakoid membranes (arrows), d-f C. polonicus from River Isar: d encysted pseudosporangium with electron dense sheath layer partly frayed in the upward part where exospores would be released, e viable cell with thylakoid double membranes distributed over the whole cell cross section (arrows); white arrowheads indicate mucus secreting pores, $\mathbf{f}$ cross section of a drought stressed exosporangium with parts of the cell wall exhibiting the many basal mucus pores (white arrow), $\mathbf{g}-\mathbf{i} C$. geitleri from River Isar, notice the wall parallel thylakoids (arrows), $\mathbf{g}$ presumably extending young exospore, $\mathbf{h}-\mathbf{i}$ details of mature exosporangia, i wall parallel thylakoids (arrow). $c b$ carboxisomes, $L$ lipid body, $P V$ pseudovagina. Scale bars: a $10 \mu \mathrm{m}, \mathbf{b}, \mathbf{g}, \mathbf{d} 1 \mu \mathrm{m}, \mathbf{c}, \mathbf{e}-\mathbf{f}, \mathbf{h}-\mathbf{i} 500 \mathrm{~nm}$

C. polonicus (9 sequences) and six individual colonies of $C$. geitleri (17 sequences) were genetically analyzed. In general, the variation within each morphospecies was high (on average $2-3.8 \%$, Table 3). Using BLASTn all obtained 16S rDNA sequences (1149-1176 bp) showed highest identity (97-99\%) with 16S rDNA of $C$. minutus PCC 6605 (Access. No. CP003600, Shih et al., 2013) or C. subglobosus PCC 7430 (access. No. AY170472). The total nucleotide variation was max. $15 \%$ and on average $3.5 \%$. The genetic variation within the ITS region was even higher and was not further analyzed (Table S4).

In order to estimate the 16S rDNA genetic variation observed within single isolated Chamaesiphon colonies, a few clones of PCR products were sequenced and the 16S rDNA nucleotide variability within one isolated colony was recorded. Within individual colonies of $C$. starmachii and $C$. geitleri a relatively low genetic variation of $16 \mathrm{~S}$ rDNA was found $(<1 \%$, Table S5). The sequences were almost identical or showed a few base pair substitutions and/or point deletions, indicating that clonal genotypes were isolated. In contrast, the $C$. polonicus colonies showed higher within-colony genetic variation $(0-5 \%)$ (Fig. 5a).

Including all sequences obtained from specific morphospecies led to an increase of the genetic diversity for the morphospecies C. starmachii (Fig. 5b). Compared with the nucleotide diversity recorded within C. starmachii colonies, the increase in nucleotide variability was due to the comparison between all isolated $C$. starmachii colonies $(n=15)$.
From the increased nucleotide variation between individual colonies assigned to $C$. starmachii, it is concluded that high genetic diversity occurred within the $C$. starmachii morphospecies.

\section{Phylogenetic analysis}

The phylogenetic maximum likelihood tree comprising 16S rDNA sequences from all major lineages of the phylum suggested that the morphogenus Chamaesiphon is most closely related to the family of Gomontiellaceae, which is phylogenetically placed among other groups of filamentous cyanobacteria that are part of the Oscillatoriales (sensu Komárek \& Anagnostidis, 2005). All Chamaesiphon sequences were found phylogenetically distinct from Geitleribactron, a sheath-lacking heteropolar cyanobacterium grouped more closely with the freshwater Leptolyngbya lineage (sensu Wilmotte \& Herdman, 2001). The same phylogenetic branching was obtained when using the Neighbor-Joining algorithm (data not shown). Notably, the most divergent strain assigned to $C$. cf. incrustans (Chamaesiphon sensu stricto sensu Komárek \& Kaštovský, 2003), which was isolated from a small spring near Reggio Emilia in Italy, was grouped with the Gomontiellaceae represented by Hormoscilla pringsheimii strain SAG 1407-1 and Crinalium epipsammum strain PCC 9333 (Fig. 6). All other Chamaesiphon individual colonies and strains (assigned to subgenus Chamaesiphon and Godlewskia sensu Komárek \& Kaštovský, 2003; Hoffmann et al., 2005) formed a distinct sister clade. However, the individual morphospecies C. starmachii, C. polonicus, and $C$. geitleri were found distributed across the entire phylogenetic branch. In this phylogeny, C. polonicus and $C$. geitleri were both located within sequences obtained from $C$. starmachii. The high genetic diversity of the $C$. starmachii morphospecies, as observed from genetic variability (Fig. 5), could be inferred from the phylogenetic tree as well. Except of $C$. cf. incrustans all other Chamaesiphon strains were also found distributed among the sequences obtained from individual Chamaesiphon morphospecies. C. geitleri strain No. 1023 clustered closely with C. starmachii and $C$. geitleri individual colonies isolated from the field. In summary, the results imply that (i) the Chamaesiphon morphospecies assigned to subgenera Chamaesiphon and Godlewskia formed a polyphyletic group, and (ii) the high nucleotide diversity with the 


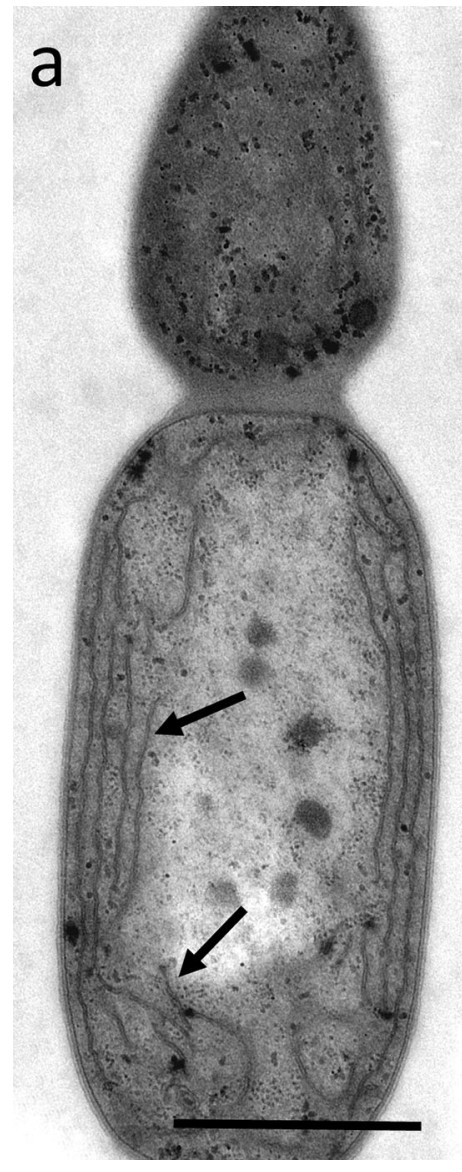

Fig. 4 Transmission electron micrographs of different Chamaesiphon spp. strains. a C. cf. incrustans No. 1036, (b, c) PCC 6605 (C. minutus), (d, e) PCC 7430 (C. subglobosus). a status in cultivation after thin layered pseudovagina had been lost, thylakoids arranged wall parallel (arrows), b cortical arrays

16S rDNA gene did not correlate with morphological diversity.

\section{Discussion}

Methodology of single colony genetic analysis

Despite its wide ecological distribution, the phylogenetic position of the genus Chamaesiphon is relatively unexplored. This is at least partly because rather few strains have been cultivated. Cultivation-independent methods such as the genetic analysis of single colonies of morphospecies can provide an alternative, which has been used successfully in the past (Mareš et al., 2015; Mareš \& Cantonati, 2016). During the isolation
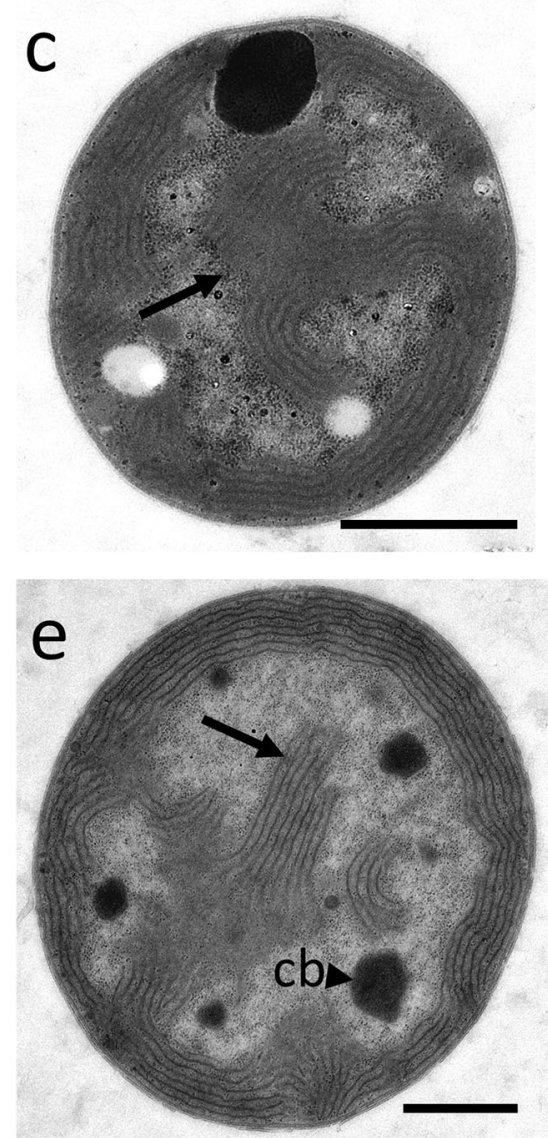

of thylakoids in older cell, $\mathbf{c}$ tangential section shows thylakoids distributed throughout the cell, $\mathbf{d}$ thylakoids organized in a few, more or less long, ribbons. e tangential section with similar appearance as in c, i.e. thylakoids protruding towards the cell center. Scale bars: $1 \mu \mathrm{m}$

procedure under the light microscope, associated taxa growing on and between Chamaesiphon colonies were observed (e.g., Homoeothrix varians), however, not recognized from 16S rDNA sequences obtained from purified Chamaesiphon colonies using the cyanobacteria-specific primers from Taton et al. (2003). In addition, small (epiphytic) coccoid cyanobacteria of the genera Aphanothece or Aphanocapsa were never observed through sequencing. The purity of the isolated colonies was supported by TEM analysis. Finally, the 16S rDNA sequences typically revealed Chamaesiphon as "closest relative" after BLASTn analysis. Thus, even if small-celled coccoid cyanobacteria would have been overlooked in the microscope, the BLASTn analysis of $16 \mathrm{~S}$ rDNA sequences would have shown their possible co-occurrence. From these 
Fig. 5 Percentage of similarity in $16 \mathrm{~S}$ rDNA sequences a within individual Chamaesiphon colonies and $\mathbf{b}$ between individual colonies of one specific Chamaesiphon morphospecies. $n=$ sample sizes of sequences (colonies), (see also Table 3 and Table S5)

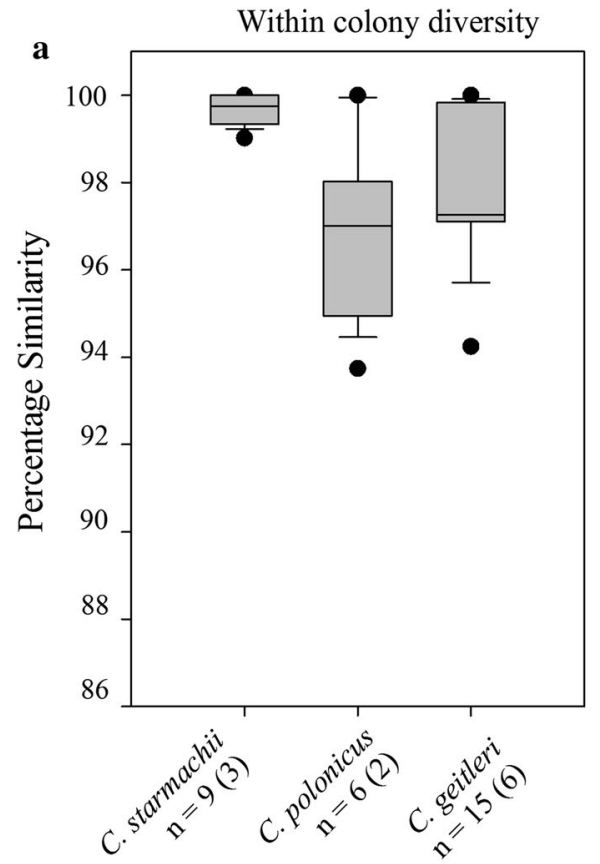

results, it is concluded that isolation and purification of Chamaesiphon colonies on agar plates was sufficiently pure to obtain Chamaesiphon-specific results.

In the TEM analysis, the morphospecies of $C$. starmachii and C. geitleri revealed mostly irregular delimited thylakoid bundles arranged in a various number of arrays along the periphery of the cells. For $C$. polonicus the irregular arrangement of the thylakoids across the cell content was observed. We suggest that during the growth and aging process a gradual detachment of thylakoids within the peripheral bundles takes place, which is similar to the observations for some Gomontiellaceae (Bohunická et al., 2015). In general, the cultivated Chamaesiphon strains, $C$. cf. incrustans No. 1036, C. minutus PCC 6605 and C. subglobosus PCC 7430 showed more regular staples of thylakoids. However, C. minutus shows the same variability in thylakoid structure as $C$. subglobosus despite that the latter species should be included into subgenus Godlewskia. This variability in thylakoid structure within PCC strains does not conform with the findings reported previously from C. subglobosus (PCC 7430, see Table 2C/g in Komárek \& Anagnostidis, 1999) and C. minutus (PCC 6605 in Gonzalez-Esquer et al., 2016). In summary, it is concluded that the variability in thylakoid ultrastructure might have been underestimated in the genus Chamaesiphon.
Chamaesiphon phylogenetic relationship as inferred from 16S rDNA gene loci

Among prokaryotes cyanobacteria are the most morphologically diverse phylum, both in aquatic and terrestrial environments. In general, the phylogeny inferred from 16S rDNA sequences corresponded with the phylogeny inferred from a larger number of gene loci obtained through genomic sequencing of more than hundred strains (e.g., Komárek et al., 2014). The only Chamaesiphon species currently with a sequenced genome, C. minutus strain PCC 6605, was found most closely related to Crinalium epipsammum PCC 9333 and the Trichodesmium-Oscillatoria PCC 7515 lineage XII (sensu Wilmotte \& Herdman, 2001), which is corresponding to the phylogenetic results based on 16S rDNA (Fig. 6). Thus it is very likely that the $16 \mathrm{~S}$ rDNA results obtained in this study will be corresponding to phylogenetic analysis obtained from sequenced genomes in the future. The high genetic diversity within the 16S rDNA gene found in the morphogenus Chamaesiphon possibly suggests a long evolutionary history. Such high diversity (on average 3.5\%, max. $15 \%$ ) is significantly above the recommended value for separation of species (Stackebrandt \& Goebel, 1994) and has forced reclassification of existing 


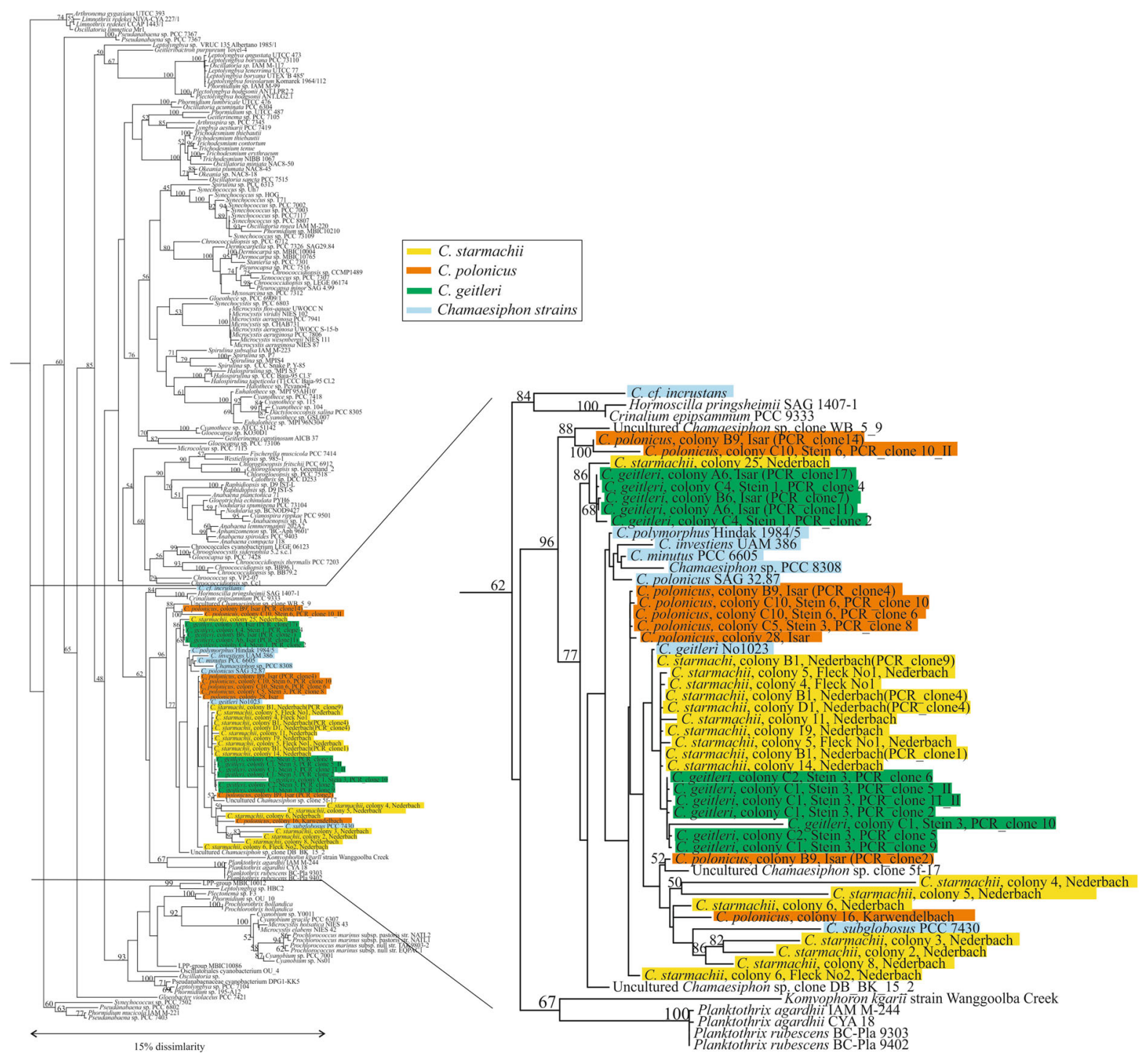

Fig. 6 Maximum likelihood phylogenetic tree calculated from 16S rDNA (1121 bp) from Chamaesiphon individual colonies and numerous cyanobacteria strains downloaded from the Ribosomal Database Project (RDP). For sequence accession numbers see Table S3. Numbers at nodes indicate the percent

genera into several independent genera, most prominently for the genus Synechococcus (e.g., Robertson et al., 2001). In contrast to Synechococcus, however, Chamaesiphon shows a much higher morphological diversity (e.g., Komárek \& Anagnostidis, 1999), which does not correspond to 16S rDNA genotyping. Furthermore, the three Chamaesiphon morphospecies analyzed by single colony genetics were found distributed over one clade, which could be assigned bootstrap frequency (1000 replicates) using RAxML (Only bootstrap values of $>50 \%$ are shown). Blue Chamaesiphon strains as listed in Table 2, yellow C. starmachii, orange $C$. polonicus, green $C$. geitleri. For sequence accession numbers see Table S3. The ML-tree was rooted using Escherichia coli

to two or even more lineages with bootstrap support. The 16S rDNA genes of the morphospecies from the Chamaesiphon strains were found intermixed with those of the single colony morphospecies with only one exception ( $C$. cf. incrustans). This phenomenon would suggest that the current Chamaesiphon subgenus classification system (Chamaesiphon s. stricto, Chamaesiphonopsis, and Godlewskia (Komárek \& Anagnostidis, 1999) is indeed polyphyletic. 
Relaxed molecular clock analyses suggested that morphological traits related to the formation of microbial mats (e.g., larger cell diameters, filamentous growth, sheath) were not visible from microfossils until the diversification of the three major lineages after 2.3 billion years (Blank \& Sanchez-Baracaldo, 2010). The same authors propose that the first largediameter filamentous microfossils to appear in the rock record at 1.9 billion years (according to Golubic \& Seong-Joo, 1999) were early members of the PNT clade (containing Pseudanabaena, Nostocales and Trichodesmium), and probably also included the early ancestors of Chamaesiphon. Epibiotic coccoid microfossils from Gaoyuzhuang Formation, Hebei Province, northern China dated 1.4 billion years ago were described to show polarized growth and cyanobacterial sheaths (Seong-Joo et al., 1999). The authors further stated that the reproductive mode of fossil epibionts corresponded to the pattern of asymmetric transverse division or budding characteristic of the extant Chamaesiphon genus. The authors emphasized large and diversified populations and the occurrence of widespread epibiosis. Thus, it seems possible that the morphological differentiation of Chamaesiphon is an old evolutionary character, which possibly evolved in response to competition for space in shallow stromatolithic-like environments.

\section{Niche diversification of Chamaesiphon morphospecies}

It is generally accepted that in unstable river beds, such as gravel pit streams, benthic cyanobacteria can persist because thick sheaths protect the cells from mechanical stress and drying (Kann, 1978). In analogy to rocky subaerial habitats, cyanobacteria can also tolerate fast-flowing and fluctuating aquatic environments by forming multiple cell wall layers of a sticky extracellular matrix, which also protect the cells from UV, drying and mechanical abrasion (Helm \& Potts, 2012). Thus the formation of multilayers in Chamaesiphon might also be understood as a response to mechanical stresses that occur in lotic habitats. Notably, a number of Chamaesiphon morphospecies in stream biofilms have been currently used in water quality assessment and bioindication (Schneider \& Lindström, 2011; Rott \& Schneider, 2014; Rott \& Wehr, 2016). This niche diversification has been attributed to both different geochemical preferences (e.g., C. fuscus (Rostafinski) Hansgirg 1888 occurs in low carbonate waters vs. C. geitleri occurs in high carbonated waters, whereas $C$. polonicus showed no geochemical preference) as well as to eutrophication (C. polymorphus is considered a eutraphentic taxon). It is not known whether specific morphospecies cannot occur under specific conditions due to physiological constrains (i.e., desiccation, excess UV radiation, shear stress) or if a particular species is competitively overgrown by a better adapted morphospecies. In either case, this ecophysiological adaptation could not be resolved by $16 \mathrm{~S}$ rDNA sequencing since closely related individual genotypes showed substantial overlap among the observed morphospecies. In other words, the most closely related 16S rDNA genotypes assigned to C. starmachii and C. geitleri occurred both in low carbonate vs. high carbonate water, respectively. The high variability in $16 \mathrm{~S}$ rDNA among Chamaesiphon morphospecies, which is not corresponding with observed ecological niches, also restricts the use of 16S rDNA genotyping for bioindication. Thus the genetic variability of the $16 \mathrm{~S}$ ribosomal gene does not allow the recognition of the three investigated morphospecies. The three morphospecies have been validly described under the ICBN based on morphological characters (Komárek \& Anagnostidis, 1999), but using the modern polyphasic approach would need to be re-evaluated, i.e., clonal cultures of individual morphospecies will need to be analyzed for exopolymer production and sheath biochemical composition, accessory carotenoid and sunscreening pigment composition, as well as ecophysiological characters such as desiccation ability. For example, special UV shielding pigments and specific pigment (phycocanin/phycoerythrin) composition were recently studied and differences found between C. starmachii/C. geitleri and C. polonicus (Siegfried Aigner, personnel communication). This conclusion is of relevance because DNA barcoding techniques are intensively discussed as a high throughput tool to characterize environmental communities. For example, diatom barcodes are used as bioindicators in the European Water Framework Directive (Rimet et al., 2016). In this study, individual Chamaesiphon morphospecies could not be recognized by means of $16 \mathrm{~S}$ rDNA, restricting the use of $16 \mathrm{~S}$ rDNA in bioassessments. We think that for a general evaluation of metabarcoding approaches, the approach used in this study (i.e. identification of cyanobacteria 
colonies and filaments in the microscope according to morphological criteria and then isolating and analyzing by PCR based methods for marker genes) could be indeed useful.

Acknowledgements Open access funding provided by Austrian Science Fund (FWF). The sample with $C$. cf. incrustans from Val Rei was provided by Marco Cantonati (Trento Italy and Drexel University Philadelphia USA). The authors would like to thank Sabrina Obwegeser (University of Innsbruck) for technical help in transmission electron microscopy sectioning and image generation. Mariona Hernandez-Mariné (University of Barcelona, Spain) assisted with most valuable hints and comments to TEM pictures. Katharina Moosbrugger and Anneliese Wiedlroither (University of Innsbruck) assisted in the laboratory with strain culturing, PCR work, cloning, and sequencing. Li Deng calculated the RAxML tree. Thomas Roach proofread the text of this manuscript. This study was supported by the Austrian Science Fund project P24070 to R.K. and also I 1951-B16 to A.H.

Open Access This article is distributed under the terms of the Creative Commons Attribution 4.0 International License (http:// creativecommons.org/licenses/by/4.0/), which permits unrestricted use, distribution, and reproduction in any medium, provided you give appropriate credit to the original author(s) and the source, provide a link to the Creative Commons license, and indicate if changes were made.

\section{References}

Blank, C. E. \& P. Sanchez-Baracaldo, 2010. Timing of morphological and ecological innovations in the cyanobacteria-a key to understanding the rise in atmospheric oxygen. Geobiology 8(1): 1-23.

Bohunická, M., J. Mareš, P. Hrouzek, P. Urajová, M. Lukeš, J. Šmarda, J. Komárek, L. A. Gaysina \& O. Strunecký, 2015. A combined morphological, ultrastructural, molecular, and biochemical study of the peculiar family Gomontiellaceae (Oscillatoriales) reveals a new cylindrospermopsin-producing clade of cyanobacteria. Journal of Phycology 51(6): 1040-1054.

Bürgi, H., P. Burgherr \& U. Uehlinger, 2003. Aquatic flora. In Ward, J. V. \& U. Uehlinger (eds), Ecology of a Glacial Flood Plain. Kluwer Academic Publishers, The Netherlands: 139-151.

Cantonati, M., E. Rott, P. Pfister \& E. Bertuzzi, 2007. Benthic algae in spring: biodiversity and sampling methods. In Cantonati, M., E. Bertuzzi \& D. Spitale (eds), The Spring Habitat: Biota and Sampling Methods. Museo Tridentino di Scienze Naturali, Trento: 77-112.

Chen, Q., G. Christiansen, L. Deng \& R. Kurmayer, 2016. Emergence of nontoxic mutants as revealed by single filament analysis in bloom-forming cyanobacteria of the genus Planktothrix. BMC Microbiology 16(1): 1-12.
Chu, S. P., 1942. The influence of the mineral composition of the medium on the growth of planktonic algae: part I. Methods and culture media. Journal of Ecology 30(2): 284-325.

Cole, J. R., Q. Wang, J. A. Fish, B. Chai, D. M. McGarrell, Y. Sun, C. T. Brown, A. Porras-Alfaro, C. R. Kuske \& J. M. Tiedje, 2014. Ribosomal Database Project: data and tools for high throughput rRNA analysis. Nucleic Acids Research 42(D1): D633-D642.

Felsenstein, J., 2004. PHYLIP (Phylogeny Inference Package). Version 3.6. Department of Genome Sciences, University of Washington, Seattle.

Golubic, S. \& L. Seong-Joo, 1999. Early cyanobacterial fossil record: preservation, palaeoenvironments and identification. European Journal of Phycology 34(4): 339-348.

Gonzalez-Esquer, C. R., J. Smarda, R. Rippka, S. D. Axen, G. Guglielmi, M. Gugger \& C. A. Kerfeld, 2016. Cyanobacterial ultrastructure in light of genomic sequence data. Photosynthesis Research 129(2): 147-157.

Gutowski, A., J. Foerster, A. Doege \& M. Paul, 2015. Chamaesiphon species in soft-water streams in Germany: occurrence, ecology and use for bioindication. Algological Studies 148(1): 33-56.

Helm, R. F. \& M. Potts, 2012. Extracellular matrix (ECM). In Whitton, B. A. (ed.), Ecology of Cyanobacteria II: Their Diversity in Space and Time. Springer, Dordrecht: 461-480.

Herdman, M., R. Castenholz, J. Waterbury \& R. Rippka, 2001. Form-genus I. Chamaesiphon Braun and Grunow 1865, emend. Geitler 1925. In Boone, D. R. \& R. W. Castenholz (eds) Bergey's Manual of Systematic Bacteriology, second edition. Springer, New York: 495-496.

Hoffmann, L., J. Komarek \& J. Kastovsky, 2005. System of cyanoprokaryotes (cyanobacteria)-state in 2004. Algolocical Studies 117(6):95-115.

Holzinger, A., M. Y. Roleda \& C. Lütz, 2009. The vegetative arctic freshwater green alga Zygnema is insensitive to experimental UV exposure. Micron 40(8): 831-838.

Iteman, I., R. Rippka, N. Tandeau de Marsac \& M. Herdman, 2000. Comparison of conserved structural and regulatory domains within divergent $16 \mathrm{~S}$ rRNA-23S rRNA spacer sequences of cyanobacteria. Microbiology 146: 1275-1286.

Kann, E., 1978. Systematik und Ökologie der Algen österreichischer Bergbäche. Arch Hydrobiol/Suppl 53: 405-643.

Komárek, J. \& K. Anagnostidis, 1999. Cyanoprokaryota, 1. Teil Chroococcales, Vol 19/1. Gustav Fischer Verlag, Jena.

Komárek, J. \& K. Anagnostidis, 2005. Cyanoprokaryota, 2. Teil: Oscillatoriales, Vol 19/2. Elsevier GmbH, Spektrum Akademischer Verlag, Heidelberg.

Komárek, J. \& J. Kaštovský, 2003. Coincidences of structural and molecular characters in evolutionary lines of cyanobacteria. Algological Studies 109(1): 305-325.

Komárek, J., J. Kaštovský, J. Mareš \& J. R. Johansen, 2014. Taxonomic classification of cyanoprokaryotes (cyanobacterial genera) 2014, using a polyphasic approach. Preslia 86(4): 295-335.

Kurmayer, R., E. Dittmann, J. Fastner \& I. Chorus, 2002. Diversity of microcystin genes within a population of the toxic cyanobacterium Microcystis spp. in Lake Wannsee (Berlin, Germany). Microbial Ecology 43: 107-118. 
Loza, V., E. Berrendero, E. Perona \& P. Mateo, 2013. Polyphasic characterization of benthic cyanobacterial diversity from biofilms of the Guadarrama River (Spain): morphological, molecular, and ecological approaches. Journal of Phycology 49(2): 282-297.

Mareš, J. \& M. Cantonati, 2016. Phylogenetic position of Geitleribactron purpureum (Synechococcales, Cyanobacteria/Cyanophyceae) and its implications for the taxonomy of Chamaesiphonaceae and Leptolyngbyaceae. Fottea 16(1): 104-111.

Mareš, J., Y. Lara, I. Dadáková, T. Hauer, B. Uher, A. Wilmotte \& J. Kaštovský, 2015. Phylogenetic analysis of cultivationresistant terrestrial cyanobacteria with massive sheaths (Stigonema spp. and Petalonema alatum, Nostocales, Cyanobacteria) using single-cell and filament sequencing of environmental samples. Journal of Phycology 51(2): 288-297.

Rimet, F., P. Chaumeil, F. Keck, L. Kermarrec, V. Vasselon, M. Kahlert, A. Franc \& A. Bouchez, 2016. R-Syst:diatom: an open-access and curated barcode database for diatoms and freshwater monitoring. Database. doi:10.1093/database/ baw016.

Rippka, R., J. Deruelles, J. Waterbury, M. Herdman \& R. Stanier, 1979. Generic assignments, strain histories and properties of pure cultures of cyanobacteria. Journal of General Microbiology 111: 1-61.

Robertson, B. R., N. Tezuka \& M. M. Watanabe, 2001. Phylogenetic analyses of Synechococcus strains (cyanobacteria) using sequences of 16S rDNA and part of the phycocyanin operon reveal multiple evolutionary lines and reflect phycobilin content. International Journal of Systematic and Evolutionary Microbiology 51(3): 861-871.

Rott, E., 2008. Chamaesiphon komárekii species nova, a new benthic freshwater chroococcalean species (Cyanophyta/ Cyanobacteria) from western coniferous forest streams in British Columbia, Canada. Algological Studies 216(1): 37-46.

Rott, E. \& S. C. Schneider, 2014. A comparison of ecological optima of soft-bodied benthic algae in Norwegian and Austrian rivers and consequences for river monitoring in Europe. Science of the Total Environment 475: 180-186.

Rott, E. \& J. D. Wehr, 2016. The spatio-temporal development of macroalgae in Rivers. In Necchi Jr., O. (ed.), River Algae. Springer International Publishing, Switzerland: 159-195.

Rott, E., E. Pipp, P. Pfister, H. van Dam, K. Ortler, N. Binder \& K. Pall, 1999. Indikationslisten für Aufwuchsalgen in österreichischen Fließgewässern. Teil 2: Trophieindikation (sowie geochemische Präferenzen, taxonomische und toxikologische Anmerkungen). Wien.

Rott, E., M. Cantonati, L. Füreder \& P. Pfister, 2006. Benthic algae in high altitude streams of the Alps - a neglected component of the aquatic biota. Hydrobiologia 562: 195-216.

Sant'Anna, C., M. Gama, M. Azevedo \& J. Komárek, 2011. New morphospecies of Chamaesiphon (Cyanobacteria) from Atlantic rainforest, Brazil. Fottea 11(1): 25-30.

Schneider, S. C. \& E. A. Lindstrom, 2011. The periphyton index of trophic status PIT: a new eutrophication metric based on non-diatomaceous benthic algae in Nordic rivers. Hydrobiologia 665(1): 143-155.

Scott, J. T. \& A. M. Marcarelli, 2012. Cyanobacteria in freshwater benthic environments. In Whitton, B. A. (ed.), Ecology of Cyanobacteria II: Their Diversity in Space and Time. Springer, Dordrecht: 271-289.

Seong-Joo, L., S. Golubic \& E. Verrecchia, 1999. Epibiotic relationships in Mesoproterozoic fossil record: gaoyuzhuang formation, China. Geology 27(12): 1059-1062.

Shih, P. M., D. Y. Wu, A. Latifi, S. D. Axen, D. P. Fewer, E. Talla, A. Calteau, F. Cai, N. Tandeau de Marsac, R. Rippka, M. Herdman, K. Sivonen, T. Coursin, T. Laurent, L. Goodwin, M. Nolan, K. W. Davenport, C. S. Han, E. M. Rubin, J. A. Eisen, T. Woyke, M. Gugger \& C. A. Kerfeld, 2013. Improving the coverage of the cyanobacterial phylum using diversity-driven genome sequencing. Proceedings of the National Academy of Sciences of the United States of America 110(3): 1053-1058.

Stackebrandt, E. \& B. M. Goebel, 1994. Taxonomic note: a place for DNA-DNA Reassociation and 16S rRNA sequence analysis in the present species definition in bacteriology. International Journal of Systematic and Evolutionary Microbiology 44(4): 846-849.

Stamatakis, A., 2014. RAxML version 8: a tool for phylogenetic analysis and post-analysis of large phylogenies. Bioinformatics 30(9): 1312-1313.

Taton, A., S. Grubisic, E. Brambilla, R. De Wit \& A. Wilmotte, 2003. Cyanobacterial diversity in natural and artificial microbial mats of Lake Fryxell (McMurdo Dry Valleys, Antarctica): a morphological and molecular approach. Appl Environ Microbiol 69(9): 5157-5169.

Wilmotte, A. \& M. Herdman, 2001. Phylogenetic relationships among the cyanobacteria based on 16S rRNA sequences. In Boone, D. R. \& R. W. Castenholz (eds), Bergey's manual of systematic bacteriology, Vol. 1, 2nd ed. Springer, New York: 487-493. 